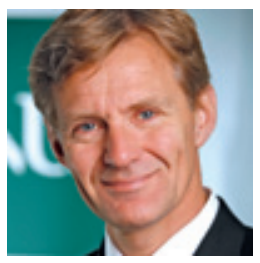

\title{
Verdens helse har blitt bedre - tross alt
}

\section{Men aldri har avstanden vært større mellom oss på toppen og milliarden på bunnen av helsepyramiden.}

Det store, eksistensielle spørsmålet for enhver generasjon har alltid vært: Blir livet bedre eller verre på vårt vaktskifte? I vår tid kan forskere og statistikere for første gang gi oss troverdige røntgenbilder av verden, men de drukner ofte i nyhetsflommen om kriser, konflikter og kjendiser. Tunge trender i vår globaliserte samtid forblir derfor skjult for mange. Verden er ofte bedre enn sitt rykte: Etter den kalde krigen er tilværelsen blitt fredeligere, tryggere og bedre for de fleste. Alle kontinenter har hatt betydelig økonomisk, sosial, medisinsk og menneskerettslig fremgang siden Berlinmurens fall for drøyt 20 år siden.

Få områder har sett så stor fremgang som helsevern og sykdomsbekjempelse. Gjennomsnittlig levealder har ifølge Verdens helseorganisasjon økt i alle verdensdeler og i nesten alle land. I 1990 døde 12,6 millioner barn under fem år helt unødvendig av sykdom som lett kan forebygges. Nå kan UNICEF konstatere at dette uhyggelige tallet, karakterkortet for hvordan vi prioriterer våre ressurser, tross alt hadde sunket til under ni millioner - selv om verdens befolkning har vokst kraftig i samme periode.

Fremgangen for den globale folkehelsen er også knyttet til nedgang $i$ analfabetismen. FNs statusrapport om gjennomføringen av tusenårsmålene viser at ni av ti barn i utviklingsland nå får skolegang.

Like viktig er det at verden er blitt fredeligere: På begynnelsen av 1990-tallet var det over 50 kriger og væpnede konflikter i verden. Nå er det under 40 konflikter i verden ifølge Institutt for fredsforskning. I Afrika var det ti kriger med over tusen drap i året i 1990. I fjor var det tre slike kriger på samme kontinent.
Bedre helsepolitikk er mange steder knyttet til fremgangen for folkestyre i verden. For 20 år siden var det flere diktaturer enn demokratier i verden. Nå er det et stort flertall demokratier. I tidligere tiår så vi flere ganger så mange militærkupp som i de siste 15 årene. Antallet folkemord og antallet sivile drept i krig eller terror har også sunket dramatisk siden 1990-tallet, ifølge Human Security Reports.

Også på det sosiale området er det fremgang: Mange hundre millioner mennesker er løftet ut av bunnløs fattigdom fra Kina til Latin-Amerika, fra Nord-Afrika til SørøstAsia. Det var dobbelt så mange mennesker under den indeksregulerte terskelen på en og en kvart dollar som Verdensbanken mener er fattigdom man knapt kan overleve på. Vi har aldri hatt en så stor overklasse og aldri en så stor middelklasse i verden som nå.

Men samtidig som et flertall får det bedre, vokser de sosiale ulikhetene i verden. Da våre tippoldeforeldre ble født $i$ et lutfattig Norge, med utbredt underernæring og voldsom barnedødelighet, var den økonomiske avstanden mellom verdens rikeste og fattigste land $1: 3$. Nå er vi blant verdens absolutt rikeste land og hundre ganger mer velstående enn verdens fattigste nasjoner. Avstanden mellom vår verdens rikeste og fattigste har aldri vært større: En håndfull av de rikeste individene er rikere enn de to milliardene i verden som har minst.

For dem som har minst, er det en liten trøst at de har klart å klatre fra 1 dollar til 2 dollar dagen når de vet at vi har gått fra 100 dollar til 200 dollar dagen. Det er en mager trøst at de ser at mange flere i barneflokken overlever dersom de ser at ingenting av den avanserte medisinske behandling vi tar som en selvfølge, tilfaller deres foreldre eller besteforeldre.

Titalls millioner fattige og arbeidsløse, men like fullt velorienterte ungdommer er rasende over det de opplever som en astro- nomisk urettferdighet mellom nasjonene og kontinentene. Disse vil forsøke å vandre fra det de ser som ulevelige kår, mot våre oaser av velstand i nord og i vest. Hvert år siden Berlinmuren falt, er mange flere blitt drept i forsøkene på å ta seg inn i Europa enn det samlede antallet som døde da de flyktet over Berlinmuren i løpet av en generasjon med kald krig.

Økonomisk verdenskrise siden 2007 har forsterket de sosiale ulikhetene. De siste to årene er titalls millioner kastet tilbake i bunnløs fattigdom hvor de må forsøke å overleve for under 8 kroner dagen. Etter 40 år med fremgang i kampen mot sult ble det 100 millioner flere sultne i de to siste årene. Det er ikke nok med frihandel for de aller fattigste. Det må også komme mer utjevning internt i vekstsamfunn som India. Og vi må gi bedre bistand og foreta flere og større investeringer som gir fattige samfunn grunnlag for utvikling og overlevelse i klimaendringenes tid. Vi kan ikke leve med stadig økende avstand mellom de samfunn som kan finansiere stadig flere kostbare kurer og inngrep for stadig mer eksotiske medisinske behov, og de samfunn som fortsatt ser at utallige barn fortsatt blør og dør fordi det ikke finnes ressurser til en fungerende primærhelsetjeneste.

En større investering i en mer rettferdig verden er ikke bare i samsvar med våre idealer. Det er også i tråd med våre interesser. Det er grenser for hvor høye murene og piggtrådsperringer kan bli i en verden i ekstrem sosial og medisinsk ubalanse.

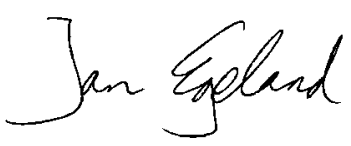

Multitraumeskader

Allmennlege i New Zealand

- Ablasjonsbehandling av arytmi
Trening og helse

Smertebehandling

- Medisinen i bilder 